\title{
American
}

Journal of

International

Law

\section{VOLUME 83}

\section{9}

Published by

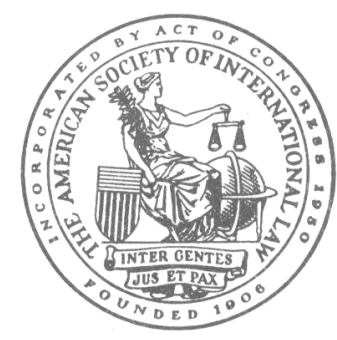

American Society of International Law 


\section{BOARD OF EDITORS}

Editor in Chief

ThOMAS M. FrancK

New York University School of Law

George H. Aldrich

The Hague, Netherlands

RICHARD B. BILDER

University of Wisconsin Law School

JONATHAN I. CHARNEY

Vanderbilt University School of Law

ANTHONY D'AMATO

Northwestern University

School of Law

Richard A. FALK

Princeton University

TOM J. FARER

University of New Mexico School of Law

Michael J. Glennon

University of California, Davis School of Law

EDWARD GORDON

Albany Law School, Union University

KeITh HigheT

The Fletcher School of Law and Diplomacy, Tufts University

JOHN H. JACKSON

University of Michigan Law School

HAROLD K. JACOBSON

University of Michigan
FREDERIC L. KIRGIS, JR.

Washington and Lee University School of Law

CyNThia C. Lichtenstein

Boston College Law School

RICHARD B. LILLICH

University of Virginia Law School

ANDREAS F. LOWENFELD

New York University School of Law

THEODOR MERON

New York University School of Law

BERNARD H. OXMAN

University of Miami School of Law

W. Michael ReISMaN

Yale Law School

WILlLIAM D. ROGERS

Washington, D.C.

Peter D. Trooboff

Washington, D.C.

DetLeV F. VAGTS

Harvard Law School

EDITH BROWN WEISS

Georgetown University Law Center

BuRns H. WESTON

University of Iowa College of Law

JoHn LAWrenCE HARgrove, Ex Officio Washington, D.C.

Herbert W. Briggs

Cornell University

\section{LEO Gross}

The Fletcher School of Law and Diplomacy, Tufts University

JOHN N. HAZARD

Columbia University School of Law

LOUIS HENKIN

Columbia University School of Law

MonRoe LeIGH

Washington, D.C.

Oliver J. LissitzyN

Columbia University School of Law

Myres S. MCDougal

Yale Law School

\section{Honorary Editors}

COVEy T. Ollver

University of Pennsylvania Law School

Stefan A. Riesenfeld

University of California, Berkeley School of Law

SEYMOUR J. RubiN

Washington College of Law, American University

OSCAR SCHACHTER

Columbia University School of Law

Louis B. SOHN

University of Georgia Law School

ERIC STEIN

University of Michigan Law School

RICHARD YOUNG

Van Hornesville, N.Y.

\section{Associate Editor \\ ANNA AsCHER \\ Editorial Assistant \\ VIRGINIA CORNETT \\ Assistant Editor Emerita \\ ElEANOR H. FinCH}




\section{AMERICAN JOURNAL \\ OF \\ INTERNATIONAL LAW}

VOLUME 83

CONTENTS

1989

[No. 1, January 1989, pp. 1-258; No. 2, April 1989, pp. 259-460;

No. 3, July 1989, pp. 461-711; No. 4, October 1989, pp. 713-1016.]

PAGE

Politics Across Borders: Nonintervention and Nonforcible Influence over Political Affairs

Lori Fisler Damrosch

Self-Defense and the Rule of Law Oscar Schachter

Applicable Law in International Arbitration: The Iran-U.S. Claims Tribunal Experience

The Alien Tort Statute and the Judiciary Act of 1789: A Badge of John R. Crook 278

Honor

Anne-Marie Burley

\section{SPECIAL ISSUE \\ THE UNITED STATES CONSTITUTION IN ITS \\ THIRD CENTURY: FOREIGN AFFAIRS}

Edited by Louis Henkin, Michael J. Glennon E William D. Rogers

Preface

The Constitution for Its Third Century: Foreign Affairs Louis Henkin History

"Advice" from the Very Beginning, "Consent" When the End Is Achieved

Arthur Bestor

The Marshall Court and International Law: The Piracy Cases

G. Edward White

713

718

727

Distribution of Constitutional Authority

Checks and Balances in Foreign Relations

President, Prime Minister or Constitutional Monarch?

The President's Foreign Affairs Power

Elliot L. Richardson

736

740

Eugene V. Rostow Phillip R. Trimble

750

How Tightly Can Congress Draw the Purse Strings? Louis Fisher

758

Rethinking War Powers: By Law or by "Thaumaturgic Invocation"?

War Powers: The Operational Code of

Thomas M. Franck

766

Competence

Nuclear War Powers

Covert Operations

Judicial Deference in Foreign Relations

Foreign Affairs and the Political Question

Doctrine

W. Michael Reisman

Peter Raven-Hansen

Lori Fisler Damrosch

Jonathan I. Charney

777

786

795

805

814

Richard B. Bilder

821

Preemption of State Law: A Recommended Analysis Harold G. Maier

832

Rights-Here and There

Foreign Affairs and Civil Liberties

Norman Dorsen

840 
The Constitution and International Human Rights Richard B. Lillich

Federal Regulation of Aliens and the Constitution

The Constitution Abroad

T. Alexander Aleinikoff

Constitutional Law-International Law

U.S. Law Enforcement Abroad: The Constitution and International Law

Andreas F. Lowenfeld

Epilogue

The Constitution and Foreign Affairs: Two Hundred Years

William D. Rogers

\section{Agora}

The Downing of Iran Air Flight 655

Introduction

Denial of Liability: Ex gratia Compensation on a Humanitarian Basis

Ex Gratia Payments and the Iranian Airline Tragedy

Marian Nash Leich

Excerpts from Report of ICAO Fact-Finding Investigation Pursuant to Decision of ICAO Council of July 14, 1988

Looking Back and Looking Ahead

Andreas F. Lowenfeld

New Thinking by Soviet Scholars

Sources of International Law: New Tendencies in Soviet Thinking

R. A. Mullerson

The Principle Pacta Sunt Servanda and the Nature of Obligation

I. I. Lukashuk

\section{Editorial Comments}

For a Permanent U.S.-Soviet Claims Commission W. Michael Reisman

Harnessing International Law to Restrain and Recapture Indigenous
Spoliations
W. Michael Reisman

Respecting One's Own Jurisprudence: A Plea to the International Court of Justice

W. Michael Reisman

The Arafat Visa Affair: Exceeding the Bounds of Host State Discretion

W. Michael Reisman

International Law in the Public Forum: The New York Times and the Libyan Chemical Weapons Plant Anthony D'Amato

Soviet Initiatives: U.S. Responses-New Opportunities for Reviving the United Nations System Thomas M. Franck

The Good Friday Accords: Legislative Veto by Another Name?

Michael J. Glennon

Senate Materials and Treaty Interpretation: Some Research Hints for the Supreme Court

Detlev F. Vagts

\section{Notes and Comments}

Nagendra Singh (1914-1988)

Edward McWhinney 342

The Francis Deák Prize

556

Anne Patricia Simons (1923-1989)

Correspondence $60,342,551$
Contemporary Practice of the United States Relating to International

Marian Nash Leich 901

Law

International Decisions
Marian Nash Leich 63, 348, 558, 905

Peter D. Trooboff $86,353,565,918$ 


\section{Current Developments}

The Settlement of Disputes under the 1988 Canada-United States

Free Trade Agreement J.-G. Castel 118

A New Approach to Human Rights: The European Convention for the Prevention of Torture Antonio Cassese 128

The Fortieth Session of the International Law Commission

$$
\text { Stephen C. McCaffrey }
$$

New Departures in the Exercise of Inherent Powers by the UN and

OAS Secretaries-General: The Central American Situation

The Space WARC Concludes

Hugo Caminos E Roberto Lavalle Milton L. Smith

United Nations Seminar on Indigenous Peoples and States

$$
\text { Russel Lawrence Barsh } 599
$$

The Forty-first Session of the International Law Commission

$$
\text { Stephen C. McCaffrey }
$$

\section{Book Reviews and Notes Edited by Detlev Vagts $172,403,605,946$ \\ Books Received $248,453,704,983$ \\ Official Documents}

United States Department of State. Statement on the Visa Application of Mr. Yassir Arafat

Organization of American States. Resolution on Agreement on Privileges and Immunities and Headquarters Agreement

Soviet Union Accepts Compulsory Jurisdiction of ICJ for Six Human Rights Conventions. Letter from Soviet Minister for Foreign Affairs to UN Secretary-General

International Legal Materials. Contents, Vol. XXVII, Nos. 5-6 (1988); Vol. XXVIII, Nos. 1-4 (1989)

Table of Cases

Index 


\section{AMERICAN JOURNAL \\ OF \\ INTERNATIONAL LAW}

VOL. 83

January 1989

NO. 1

CONTENTS

Politics Across Borders: Nonintervention and Nonforcible

PAGE

Influence over Domestic Affairs Lori Fisler Damrosch 1

Editorial Comments

For a Permanent U.S.-Soviet Claims Commission W. Michael Reisman 51

Harnessing International Law to Restrain and Recapture

Indigenous Spoliations $\quad$ W. Michael Reisman 56

Correspondence

60

Contemporary Practice of the United States Relating to

International Law

Marian Nash Leich

63

International Decisions

Peter D. Trooboff

86

Current Developments

The Settlement of Disputes under the 1988 Canada-United

States Free Trade Agreement J.-G. Castel

A New Approach to Human Rights: The European Convention for the Prevention of Torture

The Fortieth Session of the International Law Commission

Stephen C. McCaffrey

128

153

Book Reviews and Notes

Edited by Detler Vagts

Recueil des Cours de l'Académie de Droit International de La Haye, 1984. 5 vols. (Alfred P. Rubin)

Recueil des Cours de l'Académie de Droit International de La Haye, 1986.

4 vols. (Thomas Carothers)

Cassese, Antonio. International Law in a Divided World (Thomas M. Franck)

Butler, W. E. (ed.). International Law and the International System (John N. Hazard)

Tolley, Howard, Jr. The U.N. Commission on Human Rights (Roger S. Clark)

Ury, William L. Beyond the Hotline: How We Can Prevent the Crisis that Might Bring on a Nuclear War (Richard B. Bilder)

Celmer, Marc A. Terrorism, U.S. Strategy, and Reagan Policies (John F. Murphy)

De Lupis, Ingrid Detter. The Law of War (Howard S. Levie)

Boyle, Francis Anthony. Defending Civil Resistance Under International Law (Phillip R. Trimble)

Attard, David Joseph. The Exclusive Economic Zone in International Law (Bernard H. Oxman)

Dahmani, M. The Fisheries Regime of the Exclusive Economic Zone (Jon M. Van Dyke) 
Mahmoudi, Said. The Law of Deep Sea-Bed Mining: A Study of the Progressive Development of International Law Concerning the Management of the Polymetallic Nodules of the Deep Sea-Bed (Jon M. Van Dyke)

Churchill, R. R. EEC Fisheries Law (D. H. N. Johnson)

Brown, E. D., and R. R. Churchill (eds.). The UN Convention on the Law of the Sea: Impact and Implementation (David J. Bederman)

Hafner, Gerhard. Die seerechtliche Verteilung von Nutzungsrechten: Rechte der Binnenstaaten in der ausschließlichen Wirtschaftszone (Rainer Lagoni)

Legomsky, Stephen H. Immigration and the Judiciary: Law and Politics in Britain and America (Peter H. Schuck)

Hendry, I. D., and M. C. Wood. The Legal Status of Berlin (Bardo Faßbender)

Mahnke, Hans Heinrich (ed.). Dokumente zur Berlin-Frage 1967-1986 (Bardo Faßbender)

Spanger, Hans-Joachim, and Lothar Brock. Die beiden deutschen Staaten in der Dritten Welt: Die Entwicklungspolitik der DDR-eine Herausforderung für die Bundesrepublik Deutschland? (Dietrich Kappeler)

Akinrinade, Olusola, and J. Kurt Barling (eds.). Economic Development in Africa: International Efforts, Issues and Prospects (Dietrich Kappeler)

Moinuddin, Hasan. The Charter of the Islamic Conference and Legal Framework of Economic Co-operation among its Member States (Frank E. Vogel)

Bulajic, Milan. Principles of International Development Law (Samuel K. B. Asante)

Marchisio, Sergio. Il Finanziamento multibilaterale (Ida Pavesi)

Bhatt, S. Environment Protection and International Law (Tracy Dobson)

Bhatt, S. Environmental Laws and Water Resources Management (Tracy Dobson)

Nagchaudhuri, B. D., and S. Bhatt. The Global Environment Movement: A New Hope for Mankind (Tracy Dobson)

Anand, R. P., Rahmatullah Khan, and S. Bhatt. Law, Science and Environment (Tracy Dobson)

Arndt, Sven W., and Lawrence Bouton. Competitiveness: The United States in World Trade (Judith Hippler Bello)

Diebold, William, Jr. (ed.). Bilateralism, Multilateralism and Canada in U.S. Trade Policy (Judith Hippler Bello)

Gruson, Michael, and Michael Kutschera. Legal Opinions in International Transactions: Foreign Lawyers' Response to US Opinion Requests (Mark W. Janis)

Briefer Notices: Hazard, 244.

Collected Essays: The British Year Book of International Law 1985. Vol. 56, 245; Canadian Human Rights Yearbook 1986, 245; International Law of Development: Comparative Perspectives, 245; Liber Amicorum for the Rt. Hon. Lord Wilberforce, 246; Pensamiento jurídico y sociedad internacional: Libro-homenaje al profesor D. Antonio Truyol Serra. Vols. I and II, 246.

Books Received

OFFICIAL DOCUMENTS

United States Department of State. Statement on the Visa Application of Yassir Arafat

Organization of American States. Resolution on Agreement on Privileges and Immunities and Headquarters Agreement

International Legal Materials. Contents, Vol. XXVII, No. 5 (September 1988) 


\section{BOARD OF EDITORS}

Editor in Chief

Thomas M. Franck

New York University School of Law

GeOrge H. Aldrich

The Hague, Netherlands

RICHARD B. BILDER

University of Wisconsin Law School

Jonathan I. CHARNEY

Vanderbilt University School of Law

ANTHONY D'Amato

Northwestern University

School of Law

Richard A. FALK

Princeton University

TOM J. FARER

University of New Mexico School of Law

MiChaEl J. GLenNoN

University of California, Davis School of Law

EDWARD GORDON

Albany Law School, Union University

JOHN H. JACKSON

University of Michigan Law School

HAROLD K. JACOBSON

University of Michigan

FREDERIC L. KIRGIS, JR.

Washington and Lee University School of Law
Cynthia C. Lichtenstein

Boston College Law School

RICHARD B. LILLICH

University of Virginia Law School

ANDREAS F. LOWENFELD

New York University School of Law

THEODOR MERON

New York University School of Law

Bernard H. OxMan

University of Miami School of Law

W. Michael Reisman

Yale Law School

WiLliam D. Rogers

Washington, D.C.

Peter D. TroobofF Washington, D.C.

DetLeV F. VAGTS Harvard Law School

ROBERT VON MEHREN

New York, N.Y.

EDITH BROWN WEISS

Georgetown University Law Center

BURNS H. WESTON

University of lowa College of Law

John Lawrence Hargrove, Ex Officio Washington, D.C.

Herbert W. BriggS

Cornell University

LEO GROSS

Fletcher School of Law and

Diplomacy, Tufts University

JOHN N. HAZARD

Columbia University School of Law

LOUIS HENKIN

Columbia University School of Law

MoNRoe LEIGH

Washington, D.C.

OLIVER J. LISSITZYN

Columbia University School of Law

Myres S. MCDougAL

Yale Law School
Honorary Editors

COVEY T. Oliver

University of Pennsylvania Law School

Stefan A. Riesenfeld

University of California, Berkeley School of Law

SEYMOUR J. RUBIN

Washington College of Law, American University

OSCAR SCHACHTER

Columbia University School of Law

LOUIS B. SOHN

University of Georgia Law School

ERIC STEIN

University of Michigan Law School

RICHARD YOUNG

Van Hornesville, N.Y.

\section{Assistant Editor \\ ANNA AsCHER \\ Editorial Assistant \\ VIRGINIA CoRneTt \\ Assistant Editor Emerita \\ ELEANOR H. FinCH}




\section{The American Journal of International Law}

The views expressed in the articles, editorial comments, book reviews and notes, and other contributions which appear in AJIL are those of the individual authors and are not to be taken as representing the views of the Board of Editors or the American Society of International Law.

Manuscripts in triplicate may be sent to the Editor in Chief of AJIL, Professor Thomas M. Franck, New York University School of Law, 40 Washington Square South, New York, N.Y. 10012. All footnotes should be typed double space at the end of the manuscript. Please do not make multiple submissions to other journals. Persons making submissions are invited to indicate whether their manuscript is available on an IBM-PC diskette. AJIL uses WordPerfect 4.2. Subscriptions, orders for back numbers, correspondence with reference to AJIL and books for review should be sent to the AMERICAN JOURNAL OF INTERNATIONAL LAW (ISSN 0002-9300), 2223 Massachusetts Avenue, N.W., Washington, D.C. 20008-2864.

\section{The American Society of International Law}

The American Society of International Law was organized in 1906 "to foster the study of international law and to promote the establishment and maintenance of international relations on the basis of law and justice."

Society membership is open to all persons of whatever nationality and profession who are interested in its objectives. Dues are: regular, $\$ 70$; special category, $\$ 30$ for persons not resident in a member country of the Organisation for Economic Co-operation and Development; intermediate, $\$ 30$; student, $\$ 20$. Membership application form is printed at the back of each issue of AJIL.

\section{OFFICERS OF THE SOCIETY, 1988-1989}

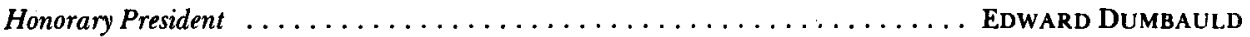

President LOUIS B. SOHN

Vice-Presidents $\ldots \ldots \ldots \ldots \ldots \ldots \ldots \ldots$ Goler Butcher, Rita HAuser, Louis Henkin

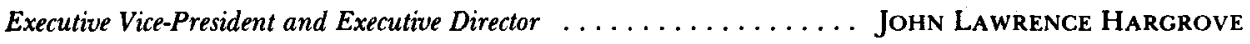

Honoray Vice-Presidents: Herbert W. Briggs, MAXwell Cohen, David G. Gill, Leo Gross, John N. Hazard, Keith Highet, Monroe leigh, Myres S. McDougal, Covey T. Oliver, Franz M. Oppenheimer, Elliot L. Richardson, Stefan A. Riesenfeld, William D. Rogers, Seymour J. Rubin, Dean Rusk, Oscar Schachter, Stephen M. Schwebel, Eric Stein, John R. Stevenson, Walter Sterling Surrey

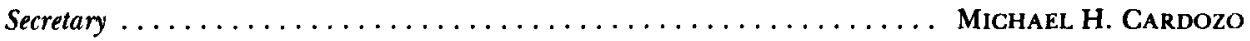

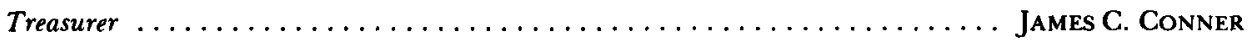

Assistant Treasurer $\ldots \ldots \ldots \ldots \ldots \ldots \ldots \ldots \ldots \ldots \ldots \ldots \ldots \ldots \ldots \ldots \ldots \ldots \ldots \ldots$ Joseph GutTENTAG 